\title{
STĀRKISIS (VĀCU STORCH) LATVIEŠU VALODAS LEKSIKOGRĀFISKAJOS AVOTOS
}

\author{
Ilga JANSONE \\ Latvijas Universitāte
}

\section{Ievads}

Latviešu valodas senās vārdnīcas sniedz ziņas ne tikai par valodā sastopamajām leksēmām, bet lielākoties arī norāda uz atbilstošu parādību, priekšmetu, dzīvu būtņu izplatību tagadējās Latvijas teritorijā. Jēdzienu stārķis (vācu Storch) apzīmējošas leksēmas sastopamas jau pirmajos leksikogrāfiskajos avotos, bet par šā putna ligzdošanas vietām un izplatîbu Latvijas teritorijā ir daudz neskaidrību.

\section{Informācija par stārḳi ornitologiskajās publikācijās}

Biolog̣ijas doktore ornitolog̣e Māra Janaus norāda, ka „Latvijā baltie stārḳi nav dzīvojuši vienmēr. Viṇu dzīvei nepieciešamas plašas, atklātas ainavas ar daudzām mitrām teritorijām - ezeriem, dịkiem, applūstošām plạavām un upju palienēm, kā arī zemnieki, kas, apstrādājot zemi, rada stārḳim labas iespējas iegūt barību [..] Pašās pirmajās publikācijās par putniem Latvijas teritorijā (18. gs. beigas - 19. gs. sākums) tiek pieminēts gan baltais, gan melnais stārkisis, bet nav ziņu par to izplatību un skaitu. Toties jau 19. gs. vidū vairāki pētnieki situāciju apraksta diezgan līdzīgi, proti: agrāk baltie stārḳi esot ligzdojuši tikai Kurzemē, to izplatības ziemeḷu robeža stiepusies gar Daugavu, bet 19. gs. pirmajā pusē putnu skaits strauji pieaudzis, tie sākuši ligzdot visā tagadējā Latvijas teritorijā.“ (Janaus 1999: 20, 22)

M. Janaus secina, ka „baltie stārķi Latvijā ir samērā neseni ienācēji. Vietējie, aborigēni, ir melnie stārķi, kuri vienmēr dzīvojuši mežos, un Latvija, kā zināms, ir bijusi un joprojām ir mežu zeme.“ (Lavrinoviča 2016) Melnais stārķis Baltijas reǵiona putnu sarakstos minēts jau 18. un 19. gadsimtā; tā izplatība raksturota gan kā reta, gan piemērotos biotopos bieži sastopama (Janaus 1995: 217-218).

Ielūkojoties vienā no senākajiem 18. gadsimta pêtījumiem par Vidzemes dabu - Jakoba Benjamina Fišera (Jacob Benjamin Fischer; 1731-1793) darbā „Versuch einer Naturgeschichte von Livland“, redzams, ka gārņu dzimtā (Reiher; Ardea L.) ietilpst gan baltais stārķis (Storch. A Ciconia. L. 84.7), gan melnais stārķis (Schwarzer Reiher A. nigra L. 84.8), bet kopīgā dzimtas 
aprakstā nav dotas norādes uz izplatības areālu un biežumu (Fischer 1778: 84-86). J. B. Fišers sniedz arī vairākus latviešu valodā sastopamus stārķa nosaukumus: Starks, Deee, Swehtelis, Swehtsputus (tā!), Schiguris (Fischer 1778: 84).

Arī Johana Melhiora Gotlība Bēzekes (Johann Melchior Gottlieb Beseke; 1746-1802) grāmatā „Beytrag zur Naturgeschichte der Vögel Kurlands..“ iekḷauts gan baltais stārḳis (A. Ciconia. 7), gan melnais stārḳis (A. Nigra. 8). Pie baltā stārķa sniegta informācija, ka tas sastopams bieži, bet pie melnā stārḳa rodama informācija par tā izskatu, kā arī norādīts, ka tas ligzdo šeit, resp. Kurzemē (Beseke 1792: 57).

\section{Stārḳa nosaukumi 17.-19. gs. latviešu valodas vārdnīcās}

Ielūkojoties „Latviešu valodas dialektu atlanta“ leksikas daḷas 36. kartē (LVDA), redzams, ka stārķim ir ļoti daudz nosaukumu, no kuriem lielākā dạ̣a iekḷauta arī kādā no senajām latviešu valodas vārdnīcām.

Pirmajā vācu-latviešu valodas vārdnīcā - Georga Manceḷa „Lettus“ vācu leksēma Storch nav sastopama (Mancelius Lettus 1638). Tai pašā 1638. gadā iznākušajā G. Manceḷa tematiskajā vārdnīcā „Phraseologia Lettica“ sadaḷā „No Puttneems“ iekḷauts vācu Storch ar latviskajiem ekvivalentiem Schugguris / Schubburis / contractè, Schuggurs (Mancelius Phr. 1638: 279).

Kristofora Fīrekera 17. gadsimta latviešu-vācu vārdnīcas pirmajā manuskriptā, kas publicēts 1997. gadā dots plašāks šķirklis Schugure. Stohrke. Germ. Ein Storch. Melna Schuggure / ein schwartzer Storch (Fürecker 1997: 239). Otrajā manuskriptā dota analoga informācija, tikai Stohrke vietā rakstīts Stahrke (Fürecker 1998: 271).

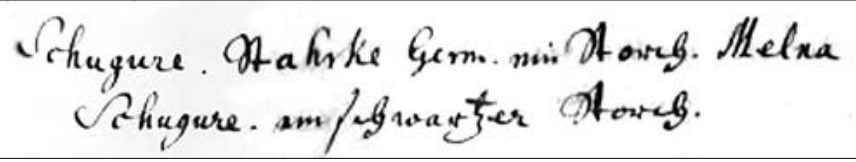

1. attēls. Šķirklis žugure K. Fìrekera vārdnīcas 2. manuskripta 368. 1pp.

(Manuskripts atrodas Latvijas Universitātes Akadēmiskajā bibliotēkā)

Georga Elgera trīsvalodu vārdnīcā „Dictionarium Polono-LatinoLottauicum“ kā poḷu Boćian nafki, latīṇu Ciconia analogs dots Zubburs / Zubburis. Zuggurs. Zugguris / gârnis / kokadzerwa (Elger 1683: 19).

Johana Langija latviešu-vācu vārdnīcā (Langijs 1685: 245) iekḷauta G. Manceḷa „Phraseologia Lettica“ sastopamā informācija (Schugguris 
(Schubburis), contractè Schuggurs, ein Storch), kas papildināta ar Kurzemē zināmām leksēmām (in Churland heift es: Dfähfis, Gandars, Swähtels).

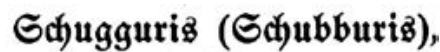 contractè Sđ̆uggurz, ein \\ Stord). in (Eburlandt

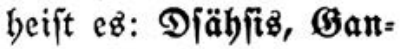 barz̆, Grwähtelz.}

2. attēls. Šķirklis žuguris J. Langija „Latviski-vāciskajā vārdnīcā“, 1685.

(Attēls no E. Bleses sagatavotā izdevuma - Langijs 1685: 245)

17. un 18. gs. mijā sastādītā „Manuale Lettico-Germanicum“ ietverti visi iepriekš minētie J. Langija vārdnīcas dati, kā arī pievienota jauna leksēma Schugdre: Schubburis, Schugguris, Schuggurs, L. J. Schugdre. Storch. in Curl. heist Dsehśis, Gandars, Swehtels. L. (Manuale 128).

Nelielajā 1705. gadā izdotajā vācu-zviedru-poḷu-latviešu vārdnīcā kā vācu Storch ekvivalenti doti Schugguris un Stahrks: Der Storch / Stork / Bocian / Tas Schugguris, Stahrks (Wörter-Büchlein 1705: 43).

Liborija Depkina latviešu-vācu vārdnīcā kā latv. Schugurs atbilsme dots vācu Storch, taču šksirklis papildināts ar sinonīmiem, vārdsavienojumiem un cilmes norādi: Stahrks. Germ: melna Schuggure / meln=Spralis. oder Sprahklis. schwarzer storch. Manc. Schubburs. et Schuggurs. (Depkin IV, 37). Aiz leksēmas Stahrks virs rindām dota atsauce uz Levit[icus] resp. 3. Mozus grāmatu. Stārķa nosaukums tiek pieminēts ne tikai 3. Mozus gr. 11:19, bet arī 5. Mozus gr. 14:18, Jeremijas gr. 8:7, İjaba gr. 39:13 un Psalmos 104:17.

1748. gadā publicētajā Kaspara Elversa vārdnīcā „Liber memorialis Letticus“ iekḷauta virkne latviešu valodas leksēmu: Storch, ftahrks, fwehts putns, fchubburis, fchugguris, dSee, melnfprahklis (Elvers 1748: 242).

Atškirīga informācija sastopama Jakoba Langes vārdnīcā. 1772. gadā izdotajā vācu-latviešu daḷa kā vācu Storch analogs iekḷauts tikai tas fchiguris (Lange 1772: 500). Savukārt latviešu-vācu dalāa ir saistītas leksēmas žūguris un žiguris: Schuhguris, aliis, Schiguris, (*,) ein Storch (Lange 1773: 286). Šai vārdnīcā ieklauta arī leksēma Stahrks tas bet ar skaidrojumu ein Sandart ${ }^{1}$ (Lange 1773, 322).

1 Sandart ir zivs nosaukums. Sal. SANDART, m. sander, zander, zant, zahnt, xant, zehand, sannat, zannaat, der hechtbarsch, perca lucioperca (Deutsches Wörterbuch von Jacob Grimm und Wilhelm Grimm; http://woerterbuchnetz.de/cgi-bin/WBNetz/wbgui_py?sigle=DWB\&mode= Vernetzung\&lemid=GS01608\#XGS01608 
Vēl J. Langes vārdnīcā atrodama arī leksēma Bugure ar skaidrojumu, ka tā dažās vietās sauc stārksi - soll einiger Orten ein Storch heissen (Lange 1773: 67).

Gotharda Frīdriha Stendera „Lettisches Lexikon“ vācu-latviešu daḷā kā vācu Storch analogi iekḷauti ftahrks, fwehts putns, melnfprahklis, kā arī ar norādi uz J. Langes ${ }^{2}$ vārdnīcu ieklạutie fchubburis, fchugguris, fchigguris, dfefe (Stender 1789 II 565-566). Nedaudz atškirīga informācija iekḷauta vārdnīcas 7. pielikumā „Putnu nosaukumi“. Šksirkḷa pirmajai daḷai paliekot nemainīgai, pievienota leksēma fwehtelis ar norādi uz izplatību tāmnieku izloksnēs, kā

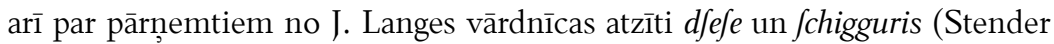
1789 II 756). Šās vārdnīcas latviešu-vācu daḷā iekḷauta lielākā daḷa iepriekšminēto leksēmu: fchigguris, Storch (ar atsauci uz J. Langi) (Stender 1789 I 244), fchubburis, Storch (ar atsauci uz G. Elversu) (Stender 1789 I 252), fchugguris, Storch (ar atsauci uz K. Elversu) (Stender 1789 I 252), ftahrks, Storch (Stender 1789 I 252), fwehts putns, Storch (Stender 1789 I 307), melnfprahklis, Storch (Stender 1789 I 289), dSefe, Storch (ar atsauci uz K. Elversu), Reiher (ar atsauci uz J. Langi) (Stender 1789 I 48). Nedaudz atšksirīga informācija ievietota 7. pielikumā „Putnu nosaukumi“: kohka dfehrwe, Storch (ar atsauci uz J. Langi) (Stender 1789 I 387), dfefe, dfeh/e, Storch (ar atsauci uz J. Langi) (Stender 1789 I 387), melnfprahklis, Storch (Stender 1789 I 388), fandards, Storch (ar atsauci uz J. Langi) (Stender 1789 I 388), fchigguris, Storch (ar atsauci uz J. Langi) (Stender 1789 I 388), fchubburis, fchugguris, Storch (ar atsauci uz J. Langi) (Stender 1789 I 388), ftahrks, Storch (Stender 1789 I 388), fwehtelis, fwehts putns, Storch (ar norādi, ka tiek lietoti tāmnieku izloksnēs) (Stender 1789 I 388).

19. gadsimta vēsturiskajās vārdnīcās atkārtojas visa iepriekšminētā informācija ar nedaudziem papildinājumiem. Jana Kurmina trīsvalodu vārdnīcā kā vienīgais poḷu Bocian analogs dots augšzemnieku dialekta Storks (Kurmin 1858: 10).

Gustava Bražes vācu-latviešu vārdnīcā kā vācu Storch ekvivalenti norādīti ftahrks un fwehtelis (Brasche 1875: 357).

Karla Kristiana Ulmaņa latviešu-vācu vārdnīcā iekḷauts gan ş̧̧irklis ftahrks (Scham. Jtarkus), der Storch, gan šķirklis Jtahrķis, kas iekḷauts kā Liepājas pusē dzirdēts kādas zivs nosaukums (Ulmann 1872: 277). Arī leksēmām fchigurs, chihgurs dotas divas nozīmes, norādot, ka nozīme 'ein Storch' sastopama Augšzemē (Ulmann 1872: 240). Daudznozīmes šķirkḷ fos fchuburs un fchugurs

2 Priekšvārdā G. F. Stenders norāda: „Nur diejenigen Wörter verantworte ich nicht, wo E. oder L. dabey stehet. Diese sind auf Autorität des Elverschen lettischen Wörterbuchs und des Langischen lettischdeutschen Lexikons hingesetzt, und müssen mit einer behutsamen Prüfung gebraucht werden." (Stender 1789, [b. lpp.]) Pārlūkojot ar L. apzīmētos vārdus, škiet, ka tie ir pārņemti gan no J. Langija manuskripta, gan no J. Langes vārdnīcas. 
dotas norādes uz citiem šķirklịem, kur noslēdzošais ir fchigurs (Ulmann 1872: 240, 241). Šai vārdnīcā iekḷauta arī leksēma fwehtelis, der Storch ar norādi uz izplatību Rietumkurzemē (Ulmann 1872: 289). Kā stārḳa apzīmējums minēts arī gandrs, der Storch ar norādi uz lietuviešu gandras (Ulmann 1872: 71). Leksēmām dfehfe, dfehfis, dfehfnis, der Storch pievienota areālā norāde, ka tā sastopama pie „Wentineeken”, kā arī iespējamā sugas norāde, ka šīs leksēmas lielākoties apzīmē melno stārḳi (der schwarze Storch) vai gārni (der Reiher) (Ulmann 1782: 56). K. K. Ulmaņa latviešu-vācu vārdnīcā sastopama arī no L. Depkina vārdnīcas pārņemtā leksēma d fehftrs, der Storch, kurai pievienots paskaidrojums, ka tā nav zināma (Nicht bekannt) (Ulmann 1872: 56).

Gustava Bražes un K. K. Ulmaņa vācu-latviešu vārdnīcas dạ̣ā vācu Storch dotas četras atbilsmes: ftahrks, fwehtelis, gandrs, klabata (Brasche, Ulmann 1880: 676).

Trīsvalodu krievu-latviešu-vācu vārdn̄icā krievu aŭcmb un vācu Storch atbilsmes ir swehtelis, starks un gandris (Waldemars 1872: 2).

\section{Stārḳa nosaukumi K. Mīlenbaha un J. Endzelīna „Latviešu valodas vārdnīcā" un tās papildinājumos}

Kārḷa Mīlenbaha un Jāņa Endzelīna „Latviešu valodas vārdnīcā“ un tās papildinājumos iekḷauta iepriekšêjās vārdnīcās publicētā informācija, kas papildināta ar precīzām areālajām norādēm, kā arī no publicētajiem avotiem iekḷauti atsevišķ līdz tam leksikogrāfiskajos avotos nefiksēti nosaukumi

\section{àzis}

K. Mīlenbaha un J. Endzelīna „Latviešu valodas vārdnīcā“ metaforiskais stārksa nosaukums dieva āzis iekḷauts no mēnešraksta „Austrums“ pēc Apsīšu Jēkaba informācijas (ME I 246 sub voce âzis). Arī nosaukumu dìevâzītis, kas ir mērkaziņas apzīmējums, Apsī̌̌u Jēkabs no Lizuma attiecina uz stārḳi (ME I 484). Starp abiem putniem nekāda līdzība nav saskatāma, grūti saskatīt arī līdzību ar āzi, kas varētu būt šā nosaukuma pārnesuma pamatā. Iespējams, nosaukums ir okazionāls lietojums. Tas nav minēts arī „Latviešu valodas dialektu atlanta“ leksikas dạ̣ā (LVDA).

\section{bugure}

Nosaukums bugure 'der Storch' ieklauts K. Mīlenbaha un J. Endzelīna „Latviešu valodas vārdnīcā“ (ME I 345) no J. Langes vārdnīcas, kur šim apzīmējumam pievienots komentārs, ka tā dažās vietās sauc stārkịi (Lange 1773: 67). Nosaukums ir pieminēts, taču nav kartografēts LVDA (98).

3 Šì informācija norādīta pie konkrētās leksēmas analīzes. 


\section{cikoniņš}

Nosaukums cikuoniņš ‘der Storch’ iekḷauts K. Mīlenbaha un J. Endzelīna vārdnīcas papildinājumos no mācītāja lubānieša Mārtiņa Celmiña vārdu krājuma (EH I 269). Kā norāda J. Endzelīns, vārds saistīts ar latīnisko stārķa apzīmējumu cicōnia. Nosaukums nav pieminēts LVDA.

\section{dzērve}

Vārdkopnosaukumu kuoka dzērve 'der Storch' J. Endzelīns iekłạ̄ivis pēc Gustava Bergmaņa manuskripta resp. K. K. Ulmaņa vārdnīcas (ME I 548). Jāpiebilst, ka vārdkopnosaukuma kuoka dzērve pirmā nozīme ir cits putns - zivju ērglis. K. Mīlenbaha un J. Endzelīna vārdnīcas papildinājumos (EH I 357) vārdkopnosaukums kuoka dzērve iekḷauts no E. Glika tulkotās Bībeles İjaba grāmatas 16. rindu. Mūsdienu tulkojumā 16. rindā nav minēts stārķa nosaukums, leksēma stārkìis resp. stārķa māte analogā kontekstā sastopama 13. rindā.

Nosaukums radies uz putnu ārējās līdzības pamata, vārdkopnosaukuma pirmajam komponentam norādot uz stārḳu ligzdošanu kokos. Latviešu dzērve, lietuviešu gervé, prūšs gerwe pamatā varētu būt putna balss skaņu atdarinājums (Karulis 1992: 249).

Nosaukums ir pieminēts, taču nav kartografēts LVDA (98).

\section{dzēse, dzēze, dzēstrs}

K. Mīlenbaha un J. Endzelīna „Latviešu valodas vārdnīcā" leksēma $d z \bar{e} s e$ iekḷauta bez vietas norādes, $d z \bar{e} s i s$ - no Kurs̄išiem, $d z \bar{e} s n i s$ - bez vietas norādes, bet kā pirmā nozīme dota vai nu melnais stārksis (pēc RLB Rakstu krājuma), vai pēc Magazīnās ieklautās informācijas pie „,ventiniekiem“ tas ir vispārināts stārķa apzīmējums (ME I 548). Tāpat šeit atrodama informācija, ka G. Manceḷa, G. Elversa un J. Langes vārdnīcās iekḷautā forma dzese ir kḷūdaina, jābūt $d z \bar{e} s e$ (ME I 548). Variants dzēze iekḷauts K. Mīlenbaha un J. Endzelīna „Latviešu valodas vārdnīcā" no RLB Konversācijas vārdnīcas ar nozīmi melnais stārḳis un J. Endzelīna piezīmi, ka varētu būt kḷūdains pieraksts no dzēse (EH I 349).

Ar nosaukumu dzēse saistīts arī cits stārķa apzīmējums $d z \bar{e} s t r s$, kas K. Mīlenbaha un J. Endzelīna „Latviešu valodas vārdnīcā“ iekḷauts no L. Depkina vārdnīcas un RLB Rakstu krājuma (ME I 349).

Vārda $d z \bar{e} s e(<* d z \bar{e} r s e)$ pamatā putna balss skaņu atdarinājums (ME I 548, Karulis 1992: 249-250).

LVDA ir pieminēts nosaukums $d z \bar{e} s i s$ no J. Langija vārdnīcas, taču tas nav kartografēts (LVDA 98).

\section{gandrs}

K. Mīlenbaha un J. Endzelīna „Latviešu valodas vārdnīcā“ sastopams arī tradicionāls melnā stārķa apzīmējums, kas attiecināts arī uz jebkuru 
stārkịi - gañdrs; tas fiksēts Trikātā, Rucavā, K. Līniņa vākumos (no Nīkrāces), Nìgrandē un Kalētos, un gan̂dris, kas pierakstīts Lielezerē (ME I 599). J. Endzelīns norāda, ka acīmredzot šis nosaukums zināms tikai Lietuvas pierobežā un aizgūts no liet. gañdras, kas savukārt līdz ar senprūšu gandams radies no gérmān̨u valodām (ME I 599). „Baltu valodu atlanta“ prospektā (BVA 99) norādīts, ka lietuviešu gañdras 'stārkịis' un latviešu gandrs 'stārķis' veido plašu kompaktu areālu, apstiprinot J. Endzelīna hipotēzi par to, ka latviešu valodā šis vārds varētu būt aizgūts no lietuviešu valodas pēc tā izplatības areāla. Tiek precizēta lietuviešu gañdras cilme. Agrāk tas tika uzskatīts par aizguvumu no Austrumprūsijas vācu valodas izloksnēm (ME I 599; Fraenkel I 133; Smoczyński 2007: 156). Pašlaik valda uzskats, ka lie. gañdras varētu būt arī ar piedēkli atvasināts onomatopoētisks baltu cilmes vārds tāpat kā prūšu *gandarus (<* gandras) (Toporov 1979: 152; Mažiulis 1988: 323; Sabaliauskas 1990: 261).

LVDA leksēma gandris vai gandrs fiksēta Dienvidrietumkurzemē Lietuvas pierobežā (LVDA 96; 36. karte). Atsevišksi šîs leksēmas pieminējumi citās Latvijas vietās nav kartogarfēti (LVDA 98).

\section{garķis, gārḳis}

Tikai K. Mīlenbaha un J. Endzelīna „Latviešu valodas vārdnīcā“ no RLB Rakstu krājuma iekḷauts baltā stārķa nosaukums garķis, kas varētu būt radies nosaukumu garnis un starķis kontaminācijas rezultātā (ME I 603). Variants gārķis minēts no Burtniekiem pēc K. K. Ulmaņa vārdnīcas (ME I 618).

LVDA fiksēts nosaukums gārkisis no Burtniekiem pēc K. Mīlenbaha un J. Endzelīna „Latviešu valodas vārdnīcas“, taču tas nav kartografēts (LVDA 98).

\section{garnis, gārnis}

K. Mīlenbaha un J. Endzelīna „Latviešu valodas vārdnīcā“ uz stārḳi attiecināts arī gārņa apzīmējums: gar̂nis sastopams Grundzālē un saistīts ar liet. garnỹs (ME I 603), bet gārnis kā stārķa apzīmējums - Smiltenē (ME I 618).

Vārda garnỹs etimolog̣ija joprojām ir diskutējama. Agrāk šo nosaukumu saistīja ar liet. gérvè, pr. gerwe (Fraenkel I 137-138; Pokorny 1969: 383 utt.). Taču tagad daži etimologi šo hipotēzi atmet, jo nav iespējams izskaidrot dažas fonētiskās pārmaiņas (Smoczyński 2007: 160). Domājams, ka liet. garnỹs ir

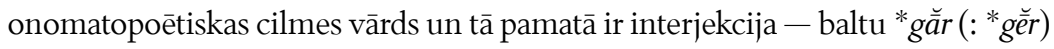
(Mažiulis 1988: 335). Pēc citu valodnieku domām (Urbutis 1981: 18, 1. par.), sakne gar- saistāma ar *ger-, sal. darbības vārdu gérti 'dzert', kas no senāka 'rīt'.

K. Mīlenbaha un J. Endzelīna „Latviešu valodas vārdnīcā“ sastopamā informācija iekḷauta arī LVDA (98), nosaukums nav kartografēts. 


\section{kārķis}

K. Mīlenbaha un J. Endzelīna „Latviešu valodas vārdnīcā“ ieklạts nosaukums kãrkịis 'der Storch' no Vilces, kas, iespējams, radies kārnis 'gārnis' un stārķis kontaminācijas rezultātā (ME II 196).

K. Mīlenbaha un J. Endzelīna „Latviešu valodas vārdnīcā“ sastopamā informācija iekḷauta arī LVDA (98), nosaukums nav kartografēts.

\section{klabata}

Metaforiskais nosaukums klabata 'der weisse Storch' K. Mīlenbaha un J. Endzelīna „Latviešu valodas vārdnīcā“ ieklạuts no RLB Rakstu krājuma (ME II 207).

LVDA nosaukums klabata minēts no dažām atstatām Latvijas vietām, piemēram, Jeriem un Ezeres; nav kartografēts (LVDA 98).

\section{krulla}

Tikai K. Mīlenbaha un J. Endzelīna „Latviešu valodas vārdnīcas“ papildinājumos ieklauts nosaukums krulla, kas Vidzemes sēliskajās izloksnēs apzīmē gan dzērvi (Lubānā), gan stārḳi (Meirānos) (EH I 659).

LVDA nosaukums krulla iekḷauts no K. Mīlenbaha un J. Endzelīna „Latviešu valodas vārdnīcas“, nav kartografēts (LVDA 98).

\section{melnsprāklis}

Baltā stārḳa nosaukums mệ̃nsprãklis ieklạts K. Mīlenbaha un J. Endzelīna „Latviešu valodas vārdnīcā“ no RLB Rakstu krājuma (ME II 599).

Nosaukums iekḷauts LVDA kā rakstu avotos fiksētais, nav kartografēts (LVDA 98).

\section{parkšksis}

K. Mīlenbaha un J. Endzelīna „Latviešu valodas vārdnīcā“ iekḷauts arī nosaukums parkšksis ar sarunvalodisko tulkojumu Klapperstorch no Jēkaba Dravnieka materiāliem (ME III 91).

LVDA nav minēts.

\section{stark-, stārk-, stork-}

K. Mīlenbaha un J. Endzelīna „Latviešu valodas vārdnīcā“" un tās papildinājumos iekḷauti vairāki šksirklị ar saknēm stark-, stārk- un stork-. Šksirklī stàrka dots variants stàrka no Praulienas bez konkrētas nozīmes, kā arī ar vācisko ekvivalentu ‘der Storch' nosaukums star̃ka no Raunas (Pētera Šmita materiāli) un Taurenes, variants ar krītošo intonāciju stàrka no Liezēres, Suntažiem, Lizuma, Saikavas, Sausnējas (Jāṇa Kauliņa materiāli), variants starka no Lubānas, starks - no Lielsalacas un Varakḷāniem, star̃ ks - no Valmieras, 
leksēma starks ieklauta arī Magazinnās ${ }^{4}$ bez vietas norādes un Pētera Šmita pasaku izdevumā no Dzirciema. Variants staṛ̂̂is sastopams Alūksnē (no RLB Rakstu krājuma), Dzelzavā, Gulbenē, variants staŗ̣̃is - Drustos (J. Cīruḷa vākumi), Zaubē, Āraišos, Skujenē, Rūjienā, bet variants stàrķis - Suntažos un Meirānos (ME III 1045). K. Mīlenbaha un J. Endzelīna „Latviešu valodas vārdnīcas“ papildinājumos variants staŗ̂̉is iekḷauts vēl arī no Vecpiebalgas, Straupes un Vecsalacas, bet intonatīvais variants staṛ̂̂is - no Alsviķiem, Jaunlaicenes un Rankas (EH II 571).

Šksirklī stārka arī iekḷauti vairāki varianti. Sieviešu dzimtes variants stārka fiksēts Pḷavin̄ās no krājuma „Etnogrāfiskas ziņas par latviešiem“ un „Filologu biedrības rakstiem“. Variants stãrks pierakstīts Cesvainē, Džūkstē un Bērzmuižā, bet stārks pārņemts no K. Ulmaņa vārdnīcas un fiksēts Purmsātos. Variants stãrķis minēts no Lielsalacas, Kandavas un Dzirciema, stārķis - no Pḷaviņām (pēc Filologu biedrības rakstiem). Šḳirkḷa ilustratīvajā materiālā minēts vēl stārks no krājuma „Etnogrāfiskas ziņas par latviešiem“ un Glika Bībeles Psalmiem 104:17. Latvju dainās sastopams variants stārka (ME III 1051). K. Mīlenbaha un J. Endzelīna „Latviešu valodas vārdnīcas“ papildinājumos leksēma stārka minēta no Pēterupes muižas, kā arī no Valmieras (no A. Bīlenšteina ierakstītiem vārdiem K. Ulmaņa vārdnīcas eksemplārā) (EH II 573). Varianta stārks izplatības areāls papildināts ar Bēni, Praviņiem un Džūksti, kā arī tas minēts Latvju dainās (EH II 573). Latvju dainās sastopams arī variants stārķis (EH II 573).

Šksirklì storķis 'der Storch' minēts, ka šī leksēma pierakstīta Dundagā, Vandzenē, Nurmuižā un Lubezerē (ME III 1080).

K. Mīlenbaha un J. Endzelīna „Latviešu valodas vārdnīcas“ papildinājumos ietverti arī vairāki stārķu mazuḷu un jaunu stārḳu apzīmējumi (ein Storchjunges): variants stãrcẹens ieklạauts no Džūkstes (EH II 573), variants star̃e êns - no Vecpiebalgas (EH II 571), starķệns - no Jāṇa Jaunsudrabiņa darbiem (EH II 571), starkulẹnn - no Vestienas (pēc „Filologu biedrības rakstiem“) (EH II 571).

Pēc „Baltu valodas atlanta“ prospektā iekḷautās informācijas (BVA 99) latviešu stārķis un lietuviešu star̃kas, kā arī to varianti parasti tiek uzskatīti par g̊ermānismiem - aizguvumiem no vlv. stark (ME III 1045; sal. vlv. stork SL IV 414; Fraenkel II 897; Karulis 1992: 286; Smoczyński 2007: 597). Tomēr Vincs Urbutis, balstoties uz vārda plašo izplatību lietuviešu valodas izloksnēs, šo uzskatu apšauba, norādot, ka vārds visdrīzāk ienācis caur latviešu valodu, nevis tieši no vācu valodas (Urbutis 2002: 18).

4 Vārdnīcā norādītais materiāls ņemts no Jelgavas skolotāia Pētera Zēvalda Birzgalē (Linden) pierakstīto vārdu saraksta, kas iekḷauts Magazīnu 13. laidiena 2. burtnīcā. 
Pēc LVDA datiem nosaukums stārķis izloksnēs sastopams samērā plaši, taču nekur tas neveido zīmīgu areālu. Vairākiem novadiem raksturīgāki ir šī nosaukuma citi fonētiskie vai morfolog̣iskie varianti. Zemgalē un Vidzemē samērā plaši izplatīti starḳis un starks, Ziemeḷkurzemē - storķis (LVDA 96-98).

\section{stāks}

K. Mīlenbaha un J. Endzelīna „Latviešu valodas vārdnīcas“ papildinājumos no Straupes ievietots šķirklis stãks ar $r$ zudumu (EH II 573).

No šejienes tas iekḷauts LVDA, nav kartografēts (LVDA 98).

\section{stērga}

K. Mīlenbaha un J. Endzelīna „Latviešu valodas vārdnīcā“ sastopams arī stārķa nosaukums stệrga, kas tur iekḷauts no Grendzes pēc A. Becenberǵera materiāliem (ME III 1063).

LVDA šis nosaukums nav minēts.

\section{stikāns}

K. Mīlenbaha un J. Endzelīna „Latviešu valodas vārdnīcas“ papildinājumos minēta leksēmas stikāns nozīme 'stārksis' no Kacēniem (EH II 578). Pamatsējumos fiksēts cita putna nosaukums ar aprakstošu skaidrojumu: 'ein Wasservogel mit langen beinen und langem Schnabel (ūdensputns ar garām kājām un garu knābi)' (ME IV 1066).

No minētajām vietām tas minēts arī LVDA, nav kartografēts (LVDA 98).

\section{svēt-}

K. Mīlenbaha un J. Endzelīna „Latviešu valodas vārdnīcā“ un tās papildinājumos iekḷauti vairāki ş̧̧irkḷi ar sakni svēt-. Variants svệtainis 'der Storch' minēts no Brizules, Lielezeres, Kursīšiem, Rengğes un Rūjienas (ME III 1154). Variants svêtelis 'der Storch (ciconia alba)' fiksēts Leitīšniekos, Aizvīksos, Apriķos, Lažā, Nīcā, Skrundā un Vērgalē, variants svètelis pārņemts no G. F. Stendera vārdnīcas ar norādi, ka sastopams tāmnieku izloksnēs, un K. K. Ulmaņa vārdnīcas ar norādi, ka sastopams Rietumkurzemē. Tāpat variants svētelis reǵistrēts Alsviķ̧os. K. Mīlenbaha un J. Endzelīna „Latviešu valodas vārdnīcas“" papildinājumos leksēma svêtelis minēta arī no Vecpiebalgas un Snēpeles, bet svêtelis - no Nīcas (EH II 617).

Variants svêtêlis minēts no Dunikas, bet svệtals (no *svẹ̄tuls?) - no Sarkanmuižas. Šai šķirklī ieklauts arī deminutīvs svệtẹlẹnns (ME III 1155). K. Mīlenbaha un J. Endzelīna „Latviešu valodas vārdnīcas“ papildinājumos škirklī svệtẹlệns iekḷauts paskaidrojums, ka svệtẹlệns nav nievājošas nokrāsas deminutīvs no svêtelis; tas ir stārķu mazulis resp. jauns stārķis (EH II 617). 
Šķirklī svệtputns 'der Storch’ šis variants norādīts no Rudbāržiem, Alsungas, Jūrkalnes un Kuldīgas, variants suệtsputns iekḷauts no J. B. Fišera pētījuma (ME III 1156).

Šķirklī svẹttulis tikai trešā nozīme ir stārḳa nosaukums 'der Storch', kas pierakstīts Ērglıos, Zaḷeniekos un Krustpilī (ME III 1156).

K. Mīlenbaha un J. Endzelīna „Latviešu valodas vārdnīcas“ papildinājumos šksirklim svètenis pievienota otrā nozīme 'der Storch', kas fiksēta Bilskā (EH II 617).

Arī škirklī sventelis ir minēta otrā nozīme 'der Storch' variantam sveñtelis no Valtaikiem (EH II 615).

Pēc „Baltu valodu atlanta“ prospektā (BVA 101) minētā, nosaukumi ar komponentu svệt-, iespējams, atvasināti no adjektīva svệts, taču iespējams, ka šim vārdam ir senāka cilme un tas saistāms ar *svēts 'gaišs, balts' (Karulis 1992: 336).

Pēc LVDA datiem kompaktā areālā Kurzemē (izņemot Ziemeḷkurzemi) lieto nosaukumu svètelis, kas pazīstams arī Vidzemē un Zemgalē. Kurzemes vidienē nelielu kompaktu areālu veido arī nosaukums svệtputns (arī svệts putns). Citi varianti ar sakni svēt- sporādiski reg̣istrēti Kurzemē (LVDA 96-98; 36. karte).

\section{štarks}

K. Mīlenbaha un J. Endzelīna „Latviešu valodas vārdnīcas“ pamatsējumos minēts šķirklis štarks no Zasas (ME IV 102).

LVDA nosaukumi ar sakni štark- fiksēti Latgales rietumu dạ̄ā un Augšzemē (LVDA 98; 36. karte).

\section{tarks, tā(r)ks}

Šksirklī tar̃ks 'starks, der Storch' fiksēts variants tar̃̂s no Baldones un Zālītes, variants tâ̂ks - no Pāles, Lielvārdes (pēc K. K. Ulmaņa vārdnīcas) un Lēdmanes (ME IV 132). Šḳirklī tãks 'der Storch' šis variants minēts no Lustes muižas (ME IV 144). Nosaukums tārciņš ‘der Storch' ieklauts bez vietas norādes (ME IV 149).

Nosaukumi tarks, $t \bar{a}(r) k s$ LVDA reğistrēti atsevišķās vietās Vidzemē un Zemgalē (LVDA 98; 36. karte).

\section{viestur-}

K. Mīlenbaha un J. Endzelīna „Latviešu valodas vārdnīcā“ iekḷauti škirkḷıi vìesturis un viesturs, kuru otrā nozīme 'der Storch' minēta no Nīcas pēc J. Janševska darbiem (ME IV 671).

LVDA pieminēts no rakstītiem avotiem, nav kartografēts (LVDA 98). 


\section{zubur-, žubur-}

Šķirklī zubur(i)s ‘der Storch’ atrodama norāde, ka nosaukums pārņemts no Elgera vārdnīcas un, ka acīmredzot tam jābūt ar $\check{z}$ (ME IV 749). Arī škirklī žuburis 'der Storch' ir redzama tikai no citām vārdnīcām ieklautā informācija: žuburis - no G. Manceḷa vārdnīcas „Lettus“ un K. Elversa vārdnīcas, žuburs - no K. K. Ulmaņa vārdnīcas (ME IV 828). K. Mīlenbaha un J. Endzelīna „Latviešu valodas vārdnīcas“ papildinājumos ieklạauta leksēma žubure no Barkavas (EH II 821).

LVDA nosaukums fiksēts tikai atsevišķās vietās Latgalē (LVDA 98).

\section{žigur-, žīgur-}

Šḳirkḷos žigurs un žl̆guris atrodama norāde vismaz uz diviem pilnīgi atšķirīgiem putniem — zvirbuli un stārķi. Variants žigurs 'ein Storch' pārņemts no K. K. Ulmaņa vārdnīcas ar izplatības areālu Augšzemē, variants žiguris 'ein Storch' - no J. Langes vārdnīcas (šis variants minēts arī no J. L. Fišera darba) (ME IV 809). Šksirklī žlouris variants ž̄̄gurs minēts no K. K. Ulmaņa vārdnīcas ar vietas norādi Augšzemē. Šeit kā ilustratīvais materiāls minēti arī atseviški tautasdziesmu varianti, kuros aprakstītais putns nav skaidri nosakāms (ME IV 813).

LVDA nav ieklauts.

\section{žugure}

Variants žugure fiksēts Lubānā (pēc izdevuma Etnogrāfiskas ziņas par latviešiem) un Latgalē (Inflantijā), konkrēti minot Barkavu, Preilus, Varakḷānus un Viḷānus, variants žuguris pārṇemts no G. Manceḷa vārdnīcas „Lettus“ un G. Elversa vārdnīcas, variants žugurs pārņemts no K. K. Ulmaņa vārdnīcas. Ilustratīvajā materiālā minēti A. Austriņa darbi un pasakas (ME IV 829).

Pēc „Baltu valodu atlanta“ prospektā norādītās informācijas (BVA 102) V. Urbutis (Urbutis 1981: 34) konstatējis, ka vārds žugure (sal. arī žūguris, zugur(i)s un zubur(i)s) ir aizgūts no lietuviešu valodas. Konstantina Sirvida pirmajā vārdnīcā fiksēta vārda žugara nozīme 'stārkisis': Ç̉apła / Ardea. Garnis / żugara. Mūsdienu lietuviešu izloksnēs šo vārdu lieto kā pejoratīvu personas apzīmējumu. Tas ir saliktenis no žuvìs 'zivs' un gérti 'dzert'.

LVDA leksēmas žugare un žugure veido samērā izteiktu areālu Latgalē (LVDA 98).

Latviešu valodas vārdnīcās nav sastopami atsevišķi 20. gs. otrajā pusē pierakstītie un LVDA ieklauautie stārķa nosaukumi. Pirmkārt, tie ir no slāvu valodām aizgūtie lielākoties Latgalē fiksētie nosaukumi: àists ( $<$ kr. aist, bkr. aist), bacàns, arī bacijans, bacjans, bacjons, bačans, bocjans ( $<$ baltkrievu dial. 
bacjan, bocjan, poḷu bocian), bočaks, kalests, arī kalusts (< kr. apv. kalist), klikuns ( $<$ kr. dial. klikun), polakss (radies ar vārda nozīmes pārnesumu, sal. kr. poljak 'polis'), žùrējs. Otrkārt, g̊ermānismi: klaperštoks. Treškārt, no personvārdiem darinātie stārķa nosaukumi: añdrējs.

\section{Secinājumi}

Latviešu valodas senajās vārdnīcās iekḷautie stārḳa nosaukumi norāda uz apzīmējumu daudzveidību. 17.-19. gs. latviešu valodas vārdnīcās iekḷauti 15 stārķa nosaukumi ar fonētiskajiem un morfolog̣iskajiem variantiem (sk. tabulu). Vairāki no šiem nosaukumiem ir citu putnu - dzērves un gārņa nosaukumi. Pēc mūsdienu klasifikācijas Latvijā sastopamā pelēkā dzērve (Grus grus) ir dzērvju dzimtas sugas putns, tā ir lielāka par stārḳi, ar garām melnām kājām un garu kaklu, apspalvojums gaišpelēks, galvas un kakla sānos balta josla, piere, rīkle, kakla priekšpuse un spārnu gali melni. Pelēkā dzērve ir gājputns (LD II 30). Daudz plašāka ir gārņu dzimta, kurā ietilpst vidēji lieli līdz lieli bridējputni ar garām kāiām, garu kaklu un knābi, kas dzīvo mitros, sekliem ūdeņiem bagātos biotopos (LD II 94). Dzēse ir zivju gārņa sinonīms, Nevar noliegt, ka visiem šiem putniem ir daudz kopīgu ārējo pazīmju — garas kājas, garš kakls un knābis.

Mūsdienu kopvalodā izplatītais nosaukums stārķis (aizguvums no vlv. stork) ar tā fonētiskajiem un morfolog̣iskajiem variantiem leksikogrāfiskajos avotos parādās 17. gadsimta otrajā pusē - K. Fīrekera vārdnīcā, kas publicēta tikai 20. gadsimta beigās pēc diviem atš̌kirīgiem norakstiem, no kuriem vienā parādās variants stohrks, bet otrā - stahrks. 17. gadsimta beigās tas līdzās citiem nosaukumiem parādās E. Glika Bībeles tulkojumos. Pēc „Seno tekstu korpusa“ datiem (senie.korpuss.lv) Bībelē fiksēts variants stārks. Iespējams, tieši no E. Glika Bībeles teksta tulkojuma nosaukums stārķis resp. stārks ieviesies latviešu valodā. Ka šis latviešu valodā ir jauninājums, rāda paralēli lietotie vācu 'der Storch' citi nosaukumi, piemēram, kohka dfehrwe (Ījaba grāmata 39:16), kas varētu norādīt, ka vēl nebija ieviesies viens stārķa nosaukums un tulkotāi izmantoja sev zināmāko variantu.

Visnoturīgākie 17.-19. gadsimta latviešu vēsturiskajās vārdnīcās ir stārķa nosaukumi žubure un žugure ar fonētiskajiem un morfolog̣iskajiem variantiem, kas 20. gadsimta otrajā pusē sastopami nelielā areālā Latgalē.

Nosaukumu daudzveidība bez skaidri izteiktiem izplatības areāliem varētu norādīt, ka virkne nosaukumu ir samērā jauni - attiecināmi uz 17.-18. gadsimtu. Ar šo laiku tiek skaidri datēta arī stārķa (pārsvarā melnā stārķa) uzturēšanās tagadējā Latvijas teritorijā. 
Tabula

Stārḳa nosaukumu secība 17.-19. gs. latviešu leksikogrāfiskajos avotos

\begin{tabular}{|c|c|}
\hline bugure & Lange 1773 \\
\hline $\begin{array}{l}\text { dzez-, dzēé-, } \\
d z e s-, d z e \bar{e}-\end{array}$ & $\begin{array}{l}\text { Langijs 1685, Manuale, Elvers 1748, Stender } 1789 \text { I, } \\
\text { Stender } 1789 \text { II, Ulmann } 1872\end{array}$ \\
\hline$d z \bar{e} s t r s$ & Ulmann 1872 \\
\hline gandr- & $\begin{array}{l}\text { Langijs 1685, Manuale, Ulmann 1872, Brasche, Ulmann 1880, } \\
\text { Waldemars } 1872\end{array}$ \\
\hline gārnis & Elger 1683 \\
\hline klabata & Brasche, Ulmann 1880 \\
\hline kokadzērva & Elger 1683 \\
\hline melnspräklis & Depkin IV, Elvers 1748, Stender 1789 I, Stender 1789 II \\
\hline sandars & Langijs 1685 \\
\hline $\begin{array}{l}\text { stārk-, stark-, } \\
\text { stork- }\end{array}$ & $\begin{array}{l}\text { Fürecker 1997, Fürecker 1998, Wörter-Büchlein } 1705 \text {, } \\
\text { Depkin IV, Elvers 1748, Lange 1773, Stender } 1789 \text { I, } \\
\text { Stender 1789 II, Kurmin 1858, Brasche 1875, Ulmann 1872, } \\
\text { Brasche, Ulmann 1880, Waldemars } 1872\end{array}$ \\
\hline svètel-, svēts putns & $\begin{array}{l}\text { Langijs 1685, Manuale, Elvers 1748, Stender } 1789 \text { I, } \\
\text { Stender } 1789 \text { II, Brasche 1875, Ulmann 1872, Brasche, } \\
\text { Ulmann 1880, Waldemars } 1872\end{array}$ \\
\hline žigur-, ž̄̄gur- & $\begin{array}{l}\text { Lange 1772, Lange 1773, Stender } 1789 \text { I, Stender } 1789 \text { II, } \\
\text { Ulmann } 1872\end{array}$ \\
\hline žubur-, zubur- & $\begin{array}{l}\text { Mancelius Phr. 1638, Elger 1683, Langijs 1685, Manuale, } \\
\text { Depkin IV, Elvers 1748, Stender } 1789 \text { I, Stender } 1789 \text { II, } \\
\text { Ulmann } 1872\end{array}$ \\
\hline žugdre & Manuale \\
\hline žugur-, zugur- & $\begin{array}{l}\text { Mancelius Phr. 1638, Fürecker 1997, Elger 1683, Langijs 1685, } \\
\text { Manuale, Wörter-Büchlein 1705, Depkin IV, Elvers 1748, } \\
\text { Lange 1773, Stender } 1789 \text { I, Stender } 1789 \text { II, Ulmann } 1872\end{array}$ \\
\hline
\end{tabular}

Vārdnīcās neietvertie lielākoties Latgalē fiksētie nosaukumi norāda, ka vārdnīcu autori pilnībā nepārzināja šai teritorijā sastopamos vārdus, kaut gan jau G. Mancel̦a „Phraseologia Lettica“ ieklautie žubure un žugure izplatīti tieši Latgalē. Iespējams, šo nosaukumu izplatības areāls 17. gadsimtā bija daudz plašāks. Nosaukumi ar žigur- un žl̆gur- varētu būt J. Langes nepareizi interpretēta forma no žugur-, jo nevienā avotā nav izdevies konstatēt, ka par žīguru sauktu stārḳi. Tas ir zvirbuḷa nosaukums, kas samērā plašā areālā izplatīts Vidzemes ziemeḷos un ziemeḷaustrumos, kā arī Latgales ziemeļos.

K. Mīlenbaha un J. Endzelīna „Latviešu valodas vārdnīcā“ un tās papildinājumos ieklauti gandrīz visi 17.-19. vārdnīcās minētie stārķa apzīmējumi, 
atsevišķos škirkḷ os izdalot vairākus fonētiskos un morfoloǵiskos variantus. Tāpat reğistrēti vairāki okazionāli vai reti sastopami nosaukumi, piemēram, cikoniņš, krulla, parkššis, stērga, stikāns, viesturs.

Stārķa nosaukumu daudzveidība norāda uz putna (īpaši baltā stārķa) samērā nesenu ligzdošanu Latvijas teritorijā, kā arī uz tā nosaukumu rašanos un motivējošām pazīmēm: nosaukuma pielīdzināšana jau zināmu putnu nosaukumiem (dzērve, gārnis, $d z \bar{e} s e$ ), raksturīgu pazīmju iekḷaušana nosaukumā (klabata, melnsprāklis, parkšksis), saistība ar mitolog̣iskiem priekšstatiem (svètelis, svēts putns).

\section{Avoti un literatūra}

Beseke, Johann Melchior Gottlieb. 1792.

Brasche, Gustav. 1875.

Brasche, Gustav, Ulmann, Carl Christian. 1880.

$\mathrm{BVA}=$

Depkin IV =

$\mathrm{EH}=$

Elger, Georgius. 1683.

Elvers, Caspar. 1748.

Fischer, Jacob Benjamin. 1778.
Beytrag zur Naturgeschichte der Vögel Kurlands mit gemalten Kupfern, Nebst einem Anhange über die Augenkapseln der Vögel von Johann Melchior Gottlieb Beseke. Mitau und Leipzig: gedruckt bey J. F. Steffenhagen.

Allererfte Anleitung zum Gebrauch der lettifchen Sprache für deutfche von G. Brafche. I. Abteilung: Grammatik, II. Abteilung: Lettifch-Deut/ches Lexikon, III. Abteilung: Deut/ch-Lettifches Lexikon, IV. Abteilung: Gefspräche. Libau: Verlag von G. L. Zimmermann.

Lettifches Wörterbuch von Ulmann und Brafche. Zweiter Theil. Deutfch-lettifches Wörterbuch mit Zugrundelegung des von Bifchof Dr. Carl Chriftian Ulmann zurükgelafsenen Manu$\int$ criptes bearbeitet von Guftav Brafche, Paftor emer. Riga u. Leipzig: Verlag von H. Brutzer \& Co.

Baltu valodu atlants. Prospekts. Rīga: LU latviešu valodas institūts, Vilnius: Lietuvių kalbos institutas, 2009.

Liborius Depkin. Lettisches Wörterbuch 4. The original manuscript transcribed and annotated by Trevor G. Fennell. Rìga: Latvijas Akadēmiskā bibliotēka, 2008 [1704].

Endzelīns, Jānis, Hauzenberga, Edīte. Papildinājumi un labojumi K. Mülenbacha „Latviešu valodas vārdnīcai“" Rīga: Kultūras fonds, 1934-1938; 2, Rīga: Grāmatu apgāds, 1946.

Dictionarivm Polono-Latino-Lottauicum. Opus posthumum. R.P. Georgii Elger ... Vilnae.

Liber memorialis Letticus, Oder Lettisches Wörterbuch, Sowohl Für die Einheimischen als Fremden / Anstat eines Lexici eingerichtet / Und allen denen zum Besten die in diesem Lande in Kirchen und Schulen Gott und ihren Nechsten dermahleins dienen / oder sonsten ihr Handel und Gewerbe treiben wollen, zu einem dienlichen Unterricht mitgetheilet von Caspar Elvers, Past zu St. Joh. und des Stadt Consistorii Assessor. Cum Gratiâ \& Privilegio Sac. Imper. Majest. Russ. Riga, 1748

Versuch einer Naturgeschichte von Livland, entworfen von J. B. Fischer. Leipzig: verlegts Johann Gottlob Immanuel Breitkopf. 
Fraenkel $=$

Fürecker $1997=$

Fürecker $1998=$

Janaus, Māra. 1995.

Janaus, Māra. 1999.

Karulis, Konstantīns. 1992.

Kurmin, Jan. 1858.

Lange, Jacob. 1772.

Lange, Jacob. 1773.

Langijs $1685=$

Lavrinoviča, Ilze. 2016.

LD II =

LVDA $=$

Mancelius Lettus $1638=$
Fraenkel, Ernst. Litauisches etymologisches Wörterbuch, 1-2, Heidelberg: Carl Winter-Gottingen: Vandenhoeck \& Ruprecht, 1955-1965.

Lettisches und Teutsches Wörterbuch zusahmen geschrieben und mit fleiß gesamlet Von Christopher Fürecker. - Trevor G. Fennell. Fürecker's dictionary: the first manuscript, Rīga: Latvijas Akadēmiskā bibliotēka, 1997.

Christoph Füreckers Candidat des Predigtamts in Kurland lettisch-deutschen Wörterbuchs erster theil A-P, zweÿter Theil R-Z. - Trevor G. Fennell. Fürecker's dictionary: the second manuscript, Rīga: Latvijas Akadēmiskā bibliotēka, 1998.

Janaus, Māra. Melnais stārkisis. Latvijas daba. Enciklopēdija. 3. sēj. Kod-Miķ. Atb. red. Guntis Kavacs. Rīga: Latvijas Enciklopēdija, 1995, 217-218.

Janaus, Māra. Latvija - stārḳu zeme. Rīga: Latvijas Zinātnes un dialoga centrs, 1999.

Latviešu etimolog̣ijas vārdnīca, 1-2. Rīga: Avots.

Słownik polsko łacinsko łotewski, ułożony i napisany przez xiędza Jana Kurmina. Wilno.

Vollftängiges Lettifches Lexicon, famt angezeigten verfchiedenen Provinzialdialekten in Lief- und Kurland. Schloß Ober=Pahlen.

Lettifch-Deutfcher Theil des volftändigen Lettifchen Lexici, darinnen nicht nur sämtliche Stammwörter diefer Sprache famt ihren Abftämlingen, fondern auch die feltene, nur in gewißen Gegenden gebräuchliche Wörter, zum Nachfchlagen, angezeigt werden. Schloß Ober $=$ Pahlen.

Lettifch-Deutfches Lexicon worinnen Der Lettifchen Sprachen Gründe, Wörter, Bedeutung vnd Gebrauch in deutfcher Sprachen gezeiget vnd erkläret werden. Sampt einer kurtzen Grammatica, wodurch Den Außländern ein richtiger Weg gewieJen wird zur Erlernung der Lettifchen Sprachen leichtlich zukommen, geftellet vnd außgegeben von Johanne Langio, Paftoren zur Ober vnd Nieder $=$ Bartaw in Curland. $-N \bar{i} c a s$ un Bārtas mācītāja Jāna Langija 1685. gada latviski-vāciskā vārdnīca ar īsu latviešu gramatiku. Pec manuskripta fotokōpijas izdevis un ar īsu apcerējumu par Langija dzīvi, rakstību un valodu papildinājis E. Blese. Rīga: Latvijas Universitāte, 1936.

Lavrinoviča, Ilze. Stārkị - svētelis vai tomēr negants gaḷēeājs? [Māras Janaus atziņas]. Latvijas Avizze, 13. septembris 2016 https://www.la.lv/starkis-svetelis-vai-tomer-negants-galedajs Latvijas daba. Enciklopēdija, 2 Don-Kṇ. Rīga: Latvijas Enciklopēdija, 1995.

Latviešu valodas dialektu atlants. Leksika. Rīga: Zinātne, 1999.

Das ift Wortbuch / Sampt angehegtem täglichem Gebrauch der Lettifchen Sprache; / Allen vnd jeden Außheimifchen / die in Churland / Semgallen vnd Lettifchem Liefflande bleiben / vnd fich redlich nehren wollen / zu Nutze verfertigt / Durch / GEORGIVM MANCELIVM Semgall. der H. Schrifft Licentiatum \&c. Erster Theil. Gedruckt vnnd verlegt zu Riga / durch Gerhard Schröder / Anno M. DC XXXVIII [1638]. 
Mancelius Phr. $1638=$

Manuale $=$

Mažiulis, Vytautas. 1988.

$\mathrm{ME}=$

Smoczyński, Wojciech. 2007.

Stender 1789 I-II =

Toporov, Vladimir N. 1979.

Ulmann, Carl, Cristian.

1872 .

Urbutis, Vincas. 1981.

Urbutis, Vincas. 2002.

Waldemars $1872=$

Wörter-Büchlein 1705 =
PHRASEOLOGIA LETTICA, Das ift: Täglicher Gebrauch der Lettifchen Sprache. Verfertigt / durch GEORGIUM MANCELIUM, Semgallum, der H. Schrifft Licentiatum \&c. Ander Theil. Diefem ift beygefüget das Spruchbuch Salamonis. Zu Riga Gedruckt vnnd Verlegt durch Gerhard Schröder/ 1638.

Manuale Lettico-Germanicum 1-2. The text of the original manuscript transcribed by Trevor G. Fennell, Rīga: Latvijas Akadēmiskā bibliotēka, 2001.

Mažiulis, Vytautas. Prūsų kalbos etimologijos žodynas, 1. A-H. Vilnius: Mokslas, 1988.

Kārla Mülenbacha Latviešu valodas vārdnīca 1-4. Redigēejis, papildinājis, turpinājis Jānis Endzelīns. Rīga: Izglīitîas ministrija, 1923-1932.

Sabaliauskas, Algirdas. 1990. Sabaliauskas, Algirdas. Lietuvių kalbos leksika, Vilnius: Mokslas, 1990.

Schiller, Karl; Lübben, August. Mittelniederdeutsches Wörterbuch, 1-5. Bremen: Verlag von J. Kühtmann's Buchhandlung, 18751880; 6, Bremen: Verlag von Hinricus Fischer, 1881.

Stownik etymologiczny języka litewskiego. Vilnius: Vilniaus universiteto leidykla.

Lettisches Lexikon. In zween Theilen abgefasset, und den Liebhabern der lettischen Litteratur gewidmet von Gotthard Friedrich Stender, Präpofitus emeritus zu Selburg, Paftor zu Selburg und Sonnaxt, und der k. d. G. zu Göttingen M. Mitau, gedruckt bey I. F. Steffenhagen, Hochfürftl. Hofbuchdrucker [1789]

Prusskij jazyk. Slovar'. E-H. Moskva-Leningrad: Nauka.

Lettifches Wörterbuch. Erfter Theil. Lettifch-deutfches Wörterbuch von Bifchof Dr. Carl Chriftian Ulmann, Riga.

Baltu etimologijos etiudai. Vilnius: Mokslas.

Pastabos dèl latvių kalbos atlase aiškinamų žodžių kilmės. Baltistica 36(1). 5-18.

Krievu-latviešu-vācu vārdnīce. Москва: Tautas Apgaismošanas Ministerija, 1872.

Wörter-Büchlein / wie Etzliche gebräuchliche Sachen auff Teutsch / Schwedisch / Polnisch und Lettisch / zu benennen feynd. Riga (1705) (Atkārtots izdevums: „Wörter=Büchlein“ Vārdnīciņa, kā dažas parastas lietas tiek dēvētas vācu, zviedru, poḷu un latviešu valodā. 1705. gadā Rīgā iznākušās vācu, zviedru, poḷu-latviešu vārdnīcas faksimiliespiedums. Ar P. Vanaga komentāriem un latviešu vārdu indeksu. Stokholma: Memento, 1999.)

Ilga Jansone

Latvijas Universitātes

Latviešu valodas institūts

Akadèmijas laukums 1, Rīga, Latvija

ilgajan@lza.lv 


\title{
SUMMARY
}

\section{Stork (German Storch) in Latvian Lexicographic Sources}

\author{
Ilga JANSONE
}

The article provides an insight into the lexicographic sources of the $17^{\text {th }}-19$ th century, as well as the names of the stork included in the K. Mühlenbach and J. Endzelinns' Latviešu valodas vārdnīca.

In the ornithological literature, reliable evidence of the presence of storks in the territory of Latvia can be found from 18th century publications, but it is mentioned that the black stork has been found in Courland even earlier.

Latvian historical dictionaries of 17th-19th century contain 15 names with phonetic and morphological versions. G. Mancelius Phraseologia Lettica had already recorded the names žuguris and žuburis, which also appear in most later dictionaries. The common name for stork (borrowed from Middle Low German stork) with its phonetic and morphological variants appears in lexicographical sources in the second half of the 17th century - in K. Fürecker's dictionary, published only at the end of the 20th century after two different transcripts, in one of which appears stohrks and in the second - stahrks. At the end of the 17th century, it appeared, among other names, in E. Glück's translations of the Bible. In addition, the names of the stork are found in dictionaries, which coincide with the names of other birds, such as kokadzerve, gārnis, dzēse. Some stork names include bird-specific features, such as klabata, melnsprāklis. The names svêtelis and svêtputns (svêts putns) reveal a connection with mythological notions. The names žigur- and žı̆gur-could be a misinterpreted form of J. Lange from žugur-, because no source has been able to state that storks would be called žigurs. It is the name of a sparrow, which is distributed in a relatively wide area in the north and northeast of Vidzeme, as well as in the north of Latgale. The stork name sandarts recorded in J. Langius dictionary could also be a mistake. Other 17th-19th century dictionaries mention the names bugure, dzēstrs and žugdre.

K. Mühlenbach and J. Endzelīns' Latviešu valodas vārdnīca include almost all the terms for stork in the dictionaries, distinguishing several phonetic and morphological variants in separate entries. A number of occasional or rare names have also been registered, such as cikoniņš̌, krulla, parkšksis, stērga, stikāns, viesturs.

The diversity of stork names indicates a relatively recent nesting of a bird (especially a white stork) in the territory of Latvia, as well as the emergence and motivating features of its names: assimilation of the name to the names of already known birds (dzērve, gārnis, dzēse), inclusion of characteristic features in the name (klabata, melnsprāklis, parkšşis), connection with mythological notions (svêtelis, svêts putns). This hypothesis is also confirmed by the fact that the names of the stork mostly do not form compact dialectal areas. 